12. Gamezo M. V. Atlas in psychology: information-methodical manual for the 'Human Psychology' course /M.V. Gamezo, I.A. Domashenko - M.: Pedagogical Community of Russian Federation, 1999 - 276 p.

МРНТИ 14.01.11

https://doi.org/10.51889/2020-1.1728-5496.58

\author{
S.S. Seytenova ${ }^{1}$, A.S. Abil ${ }^{2}$ \\ ${ }^{1,2}$ Aktobe Regional State University K.Zhubanova
}

\title{
INCREASING INTEREST IN STUDYING STUDENTS BY USING INTERACTIVE METHODS IN THE CONDITIONS OF UPDATED EDUCATION CONTENT
}

Abstract
This article focuses on identifying effective interactive teaching methods and using interactive teaching methods in such a way as to motivate students to read in the context of updated educational content. There are three levels of active learning. The article outlined the basic rules for using active and interactive methods to stimulate students' exercise.It also contains criteria to guide the teacher in choosing methods and several types of active and interactive learning tools to encourage students to practice in the context of updated educational content. It presents the expected results of the proposed approaches, the steps that need to be taken, a system of ways in which elementary school students can increase their motor, social, cognitive and communicative activity. The article states that they play a special role in teaching elementary school students, and this game should be conducted as a teaching method.

Keywords: updating, educational content, motivation, asset, methods, selection, analysis, use, effectiveness, concepts, definition.

\author{
С.С. Сейтенова ${ }^{1}$ А.С. Абил ${ }^{2}$ \\ ${ }^{1,2}$ Қ.Жұбанов ат. Ақ̆төбе өңірлік мемлекеттік университеті
}

\section{ЖАНАРТЫЛҒАН БІЛІМ БЕРУ МАЗМҰНЫ ЖАҒДАЙЫНДА ОҚУШЫЛАРДЫҢ ОҚУҒА ЫНТАСЫН ИНТЕРБЕЛСЕНДІ ӘДІСТЕР АРҚЫЛЫ АРТТЫРУ}

Бұл мақалада жаңартылған білім беру мазмұны жағдайында оқушылардың оқуға ынтасын интербелсенді әдіс-тәсілдер арқылы арттыру жолдарын қарастырған және интерактивті әдістәсілдерін ұсынған, саралап қолданудың тиімділігін және оқытудың белсенді, интерактивті әдістері ұғымдарының анықтамасына тоқталған. Оқытудың белсенді әдісінің үш деңгейін атап көрсеткен. Окушыларды жаттығу орындауды ынталандыруға бағытталған белсенді және интерактивті әдіс тәсілдерді қолдану кезіндегі негізгі ережелерін атаған. Әдіс-тәсілдерді таңдауда мұғалімдердің басшылыққа алатын критерийлерін және жаңартылған білім беру мазмұны жағдайында оқушыларды жаттығу орындауға ынталандырудың белсенді және интерактивті әдіс-тәсілдерінің бірнеше түрлерін ұсынған. Ұсынған әдіс-тәсілдердің күтілетін нәтижелерін, жүзеге асыру қадамдарын, бастауыш сынып оқушыларының қимыл, әлеуметтік, танымдық, қатысымдық белсенділіктерін арттыру жолдарының жүйесін көрсеткен. Бастауыш сынып оқушыларын оқыту кезінде ерекше орынды ойын алатындығын және ойын бұл жерде оқыту әдісі ретінде жүргізілуі қажеттігі айтылған.

Түйін сөздер: жаңартылған, білім беру мазмұны, ынталандыру, белсенді, әдіс-тәсілдер, таңдап, саралап, қолдану, тиімді, ұғымдар, анықтама.

\section{С.С.Сейтенова ${ }^{1}$ А.С. Абил ${ }^{2}$}

\footnotetext{
${ }_{1,2}$ Актюбинский региональный государственный университет им. К.Жубанова
} 


\title{
ПОВЫШЕНИЕ ИНТЕРЕСА К УЧЕБЕ УЧАЩИХСЯ С ПОМОЩЬЮ ИНТЕРАКТИВНЫХ МЕТОДОВ В УСЛОВИЯХ ОБНОВЛЕННОГО СОДЕРЖАНИЯ ОБРАЗОВАНИЯ
}

\begin{abstract}
Аннотация
В этой статье основное внимание уделяется определению эффективных интерактивных методов обучения и использованию интерактивных методов обучения таким, образом чтобы мотивировать учащихся читать в контексте обновленного образовательного контента. Есть три уровня активного обучения. В статье изложили основные правила при использовании активных и интерактивных методов для стимулирования упражнени учащихся. Также содержит критерии для руководства учителя при выборе методов и несколько типов активных и интерактивных сопособов, чтобы побудить учащихся практиковаться в контексте обновленного образовательного контента. В нем представлены ожидаемые результаты предлагаемых подходов, шаги, которые необходимо предпринять, система способов, с помощью которых учащиеся начальной школы могут повысить свою двигательную, социальную, когнитивную и коммуникативную активность. В статье указано, что они играют особую роль в обучении учащихся начальной школы, и эта игра должна проводиться как метод обучения.
\end{abstract}

Ключевые слова: обновление, содержание образования, мотивация, актив, методы, отбор, анализ, использование, эффективность, концепции, определение.

The updated educational program implemented in the country's educational process is focused on a competency-based approach and quality that meets the needs of future generations. The main goal of the updated educational program is not only to update the content of education but also to introduce a system of evaluation through criteria and improve the effectiveness of various methods of training. In the XXI century, it is necessary to focus on a new direction chosen by the advanced countries of the world, to actually achieve a system aimed at personal development, its stimulation. In the project of the state program for the development of education in Kazakhstan for 2011-2020, much attention is paid to improving the Kazakh education system. First of all, in increasing the status and developing the qualifications of teaching staff. In this regard, currently, reforms, changes, and innovations in the country's education system are the basis for working with new ideas, thinking about the past, present, future, and future of the teacher [1].

Each lesson should achieve the goal by analyzing certain methods and techniques. In this regard, the requirement for an updated content of education is the ability and selective application of strategies, methods, and techniques to optimally achieve the expected learning outcomes. Therefore, the teacher should strive to develop the creative abilities of students by widely applying new methods and techniques during the lesson.

Before presenting active and interactive methods to encourage students to perform exercises in the updated content of education, let us focus on defining the concepts of active and interactive teaching methods.

Active learning methods are a way to activate the educational and cognitive activity of students during the lesson.

Interactive learning methods ("Inter" - interaction, " act " - interaction) are ways to ensure interaction [2].

In the active method of teaching, teachers characterize the exercises offered to the student and the ways of the task that organize its independent implementation, in which they interact with each other and this attitude assumes a democratic style. Thestudentdemonstratesthreelevelsofactivity:

- Simulation activity-comprehension and application of knowledge while performing tasks on the model, updating knowledge;

- Analysis, a generalization of information and use of knowledge in modified cases;

- Creative activity-creative problem-solving.

The interactive method is dominated by the subject-subjective activity of the teacher and student. At the same time, the student is focused on interacting not only with the teacher but also with each other. Interactive learning is a Dialogic learning, joint activity of students, in an atmosphere of kindness and mutual support, providing spiritual and emotional cooperation of participants. When using active and interactive methods and techniques aimed at encouraging students to perform exercises, the following main points should be taken into account:

1. All students must participate in the exercises; 
2. Encouragement for the activity of students, providing psychological readiness to perform certain exercises in various ways.;

3. Students should not be in a group, the rational number of students is $25-30$ students. This is a condition for ensuring the result of work in small groups;

4. The learning space should be such that students can easily navigate through each group for work. The table should be set as "Christmas trees", i.e. each student should be able to communicate with his small group so that he half-turns the teacher;

5. Use different ways to divide students into groups: the principles of choice of freedom, randomness.

In this regard, active methods and interactive methods of performing exercises differ in the features of interaction of participants in the educational process, depending on how the training is carried out. It can be attributed to an active or interactive method of training. For example, the cluster method can be used for individual work, and it will become an active learning method. This method provides an interactive learning mode when filled in in a pair or group. Tasks:

- Increasing students' interest in performing exercises;

- Effective development of educational material;

- Developing the ability to independently perform these exercises, developing the ability to independently find the necessary information;

- Development of students' communication skills, ability to work in a team;

- Forming students' opinions and views;

- Arouse interest in performing exercises using effective ways to stimulate students.

While choosing correct teaching methods, it is better to remind L. N. Tolstoy's words: "Knowledge is only knowledge when it is acquired by the effort of one's thought, not by memory.".

When choosing methods and techniques, the teacher should be guided by the following criteria:

- In accordance with the rules, expected results, and training goals;

- The content of the topic;

- Compliance with students ' abilities: psychological development, age characteristics, level of education;

- Compliance of the teacher's capabilities: pedagogical experience; experience of mastering methods

- Technological capabilities of the educational process.

In the context of the updated content of education, active and interactive methods of stimulating students to perform exercises should be noted.

The method of "Association".

Expected result.

Thestudentcando:

- Updating knowledge about the problem;

- Presenting your knowledge about the problem;

- Ability to clearly show the scheme of the received information;

- Preparation of a full resume on the proposed topic;

- Ability to communicate in the process of cognitive activity.

- Implementation steps:

- Step 1: Draw a circle, enter the name of the theme in the center. For example, "suffix and ending".

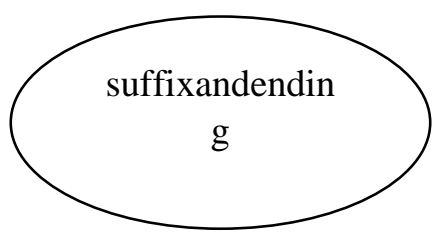

Step 2: Write down in a notebook the information they know depending on the topic, first print the results, and then discuss in a subgroup.

Step 3: Presentation in the classroom on the topic for all groups.

A method of "The cluster"

Expected results

The student can do:

- Updating knowledge on the topic under study; 
- To present their knowledge about the subject;

- Show it with a visual bag;

- Establishing a thematiclink;

- Creating a fullresume.

Implementationsteps:

Step 1: Create a cluster on the topic "Winter".
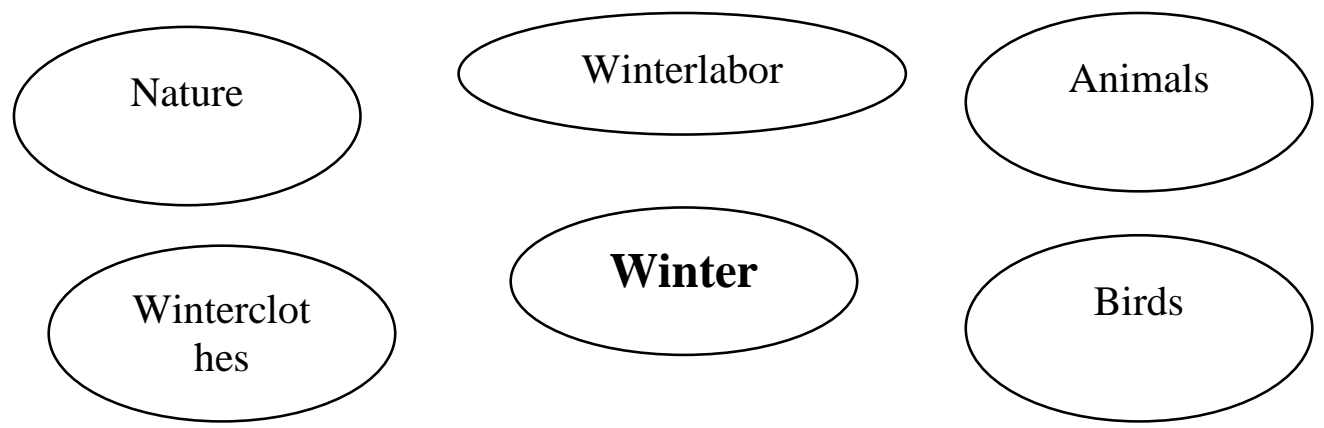

Step 2: Students should write what is familiar to them in their notebooks on this topic.;

Step 3: Group discussion about the writings of an individual student, preparing a general response on behalf of the group;

Step 4: Write the responses of the group on the board.

"INSERT" or "Touch" method

Implementation steps:

Step 1: Read the text, for example, "school, school team".

"V" - familiar to me;

"+" - new to me;

"- " - doesn't match with the concept I know;

"?" - I would like to learn more about this.

Step 2: Pair-by-pair discussion of the results, and then create a table and discuss with the group:

\begin{tabular}{|c|c|c|c|}
\hline$\ll \mathbf{V} »$ & «+» & «-» & $\ll ? »$ \\
\hline & & & \\
\hline
\end{tabular}

Step 3: Search for answers to the questions in the last column.

Subject "Kazakh language" plays a huge role in the educational and methodological complex. The educational and methodological complex of the subject "Kazakh language" involves the development of the following broad skills in primary school students:

- Functional and creative application of knowledge;

- Criticalthinking;

- Conductingresearch;

- Use of information and communication technologies;

- The uses of different methods of communication;

- Ability to work in groups, pairs, and individually;

- Problem-solving and decision-making skills;

- Ability to apply acquired knowledge in life.

The use of interactive methods in "Kazakh language" lessons opens opportunities and increases the interest of primary school students, develops their activity[3].

With the help of interactive methods, students become free during classes, and cognitive and communicative connections are closely linked. Interactive methods and techniques used in the initial learning process allow students to be active in the classroom and interact with the learning material. Ways to increase the motor, social, cognitive, and communicative activity of primary school students can be systematized as follows: 
1. Ways to increase the motor activity of students: free atmosphere for asking help from another student; help from the best student to the worst one; communication of students in their groups on the task; their mutual verification after completing the task.;

2. Development of social activity of students: their mutual respect for each other in the form of "student-student" or "teacher-student", "student-teacher"; mutual enrichment in the classroom; freedom of answers to difficult questions of students of the opposite group.;

3. Ways to increase the cognitive activity of students: to express their attitude to the group's opinion; to argue their point of view in case of disagreement; to express their supportive opinion about team members opinion; to be able to self-evaluate and provide feedback to their activities.;

4. Ways to increase students' communicative activity: free speech communication of students during the lesson; joint planning of responses; clear and concise presentation of spoken words; ability to effectively express their thoughts; purity of speech of the speaking jargon, dialect.

While using interactive methods and techniques, a class can be divided into two or three or four cell groups, given one task for all, or a separate task for each group.

In the course of training practice, it demonstrates the effectiveness of using interactive methods based on discussions, developing the student's educational reflection, and using didactic games in the learning process. In particular, didactic games, reflexive exercises and tasks help to increase the activity of students in learning, correct application of the acquired knowledge in practice. In the course of completing tasks, students achieve such abilities as the orientation of the situation, ability to analyze the situation, awareness of their role in the situation, establishing contacts between colleagues participating in the conversation, the ability to correctly use language concepts in communication, and have feedback on their activities.

A special place in the education of younger students is occupied by the game. The game takes place here as a method of learning. The interest of students of this age in the game will prevail. Therefore, it is advisable to use a large number of game methods to stimulate students. The game is both educational and labor-intensive for children. The game is a way of knowing the world around you. It not only teaches students to overcome the difficulties they face in life but also forms organizational skills. "The game is very important for students, children's game, as important as the work, activity of adults, and is important for them. When the child has grown up, his decisions and actions at work will most often be the same as ingame. Therefore, the future figure, first of all, receives education through the game," she said.

The following methodological requirements apply to the game:

- The goal of the game should be clear and prepare in advance for the necessary visual and material materials;

- Before starting the game, explain the procedure in detail to students;

- Ensuring that students participate in the game in the classroom;

- Ability to make decisions during the game, ability to think;

- Selection of game types in accordance with the program;

- Using the game depending on the student's age;

- Be sure to publish the results of the game [4].

The main task of the game in primary school is to develop students ' intelligence, enrich knowledge, and develop the motor activity. Depending on the content, games are divided into story-role-playing, didactic games, outdoor games, and national games.

The game "Route" - the last letter of the pronunciation word is filled in the cells located in the same sequence so that the last letter of this word is the first letter of the next word.

The game "Right or Wrong". Participants in the game must be divided into groups and sit opposite each other. Participants in the two groups are given yellow and green cards. The green card is "correct", the yellow card means "incorrect". The teacher reads a thought from paper, according to which the participants in both groups pick up the cards. Each group that first picks up and chooses the correct answer becomes the winner.

The game "Rainbow". The task is given to quickly speak five-pointed objects of different colors in order. If you do not find the name of the item by the specified color, you are out of the game [6].

Nowadays, there are many methods and techniques that are used in educational activities. The content features of the subject "Kazakh language" requires perfect knowledge and choice of strategies, methods, and techniques that allow to optimally achieve the expected results and develop the educational reflection of students. We have shown several models of effective ways, games, to encourage students to perform exercises in the 2nd grade in the Kazakh language, taking into account the age characteristics of students. 
Thus, if the teacher fully mastered the approach to his lesson, was able to develop the interest and desire of students, then he successfully achieved his goal.

\title{
References:
}

1. State program of education development in Kazakhstan for 2011-2020

2. Imzharova Z. U. Active and interactive teaching methods of pedagogical disciplines. - Aktobe: publication, ARSU. K. Zhubanova, 2004. - 5-48C.

3. Zhumabayeva V. E. and others. Kazakh language. Teaching method. In two parts. For teachers of 2nd grade of secondary schools / Schools.Sh. Zhumabaeva, M. N. Ospanbekov. - Almaty: Publishing house of KazGU. Al-Farabi, 2017.-4 pages.

4. Republican scientific and methodological journal. Education and upbringing in primary schools. No. $1-2 / 2016$.

5. Republican scientific and methodological journal. Education and upbringing in primary schools. No. $11-12 / 2017$.

6. Actual scientific research in the modern world. Materials of the $V$ International scientific and practical Internet conference. January 2015 S. O. January 2015

МРНТИ 14.29.27

https://doi.org/10.51889/2020-1.1728-5496.59

\author{
А.Н.Аутаева ${ }^{1}$, С.Сеитимбетова ${ }^{2}$ \\ ${ }^{12}$ Абай атындагы ұлттық педагогикалық университеті, \\ Алматы қ̧., Қазақ̧стан
}

\section{ЕСТІУІНДЕ АУЫТҚУЫ БАР ОҚУШЫЛАРДЫ АҒЫЛШЫН ТІЛІНЕ ОҚЫТУДА ВЕРБОТОНАЛЬДЫ ӘДІСТІ ҚОЛДАНУ МӘСЕЛЕСІНІН НЕГІЗДЕРІ}

Естуінде ауытқуы бар оқушыларды ағылшын тіліне оқытуда верботональды әдісті қолдану мәселесі қарастырылған. Есту қабілеті нашар балаларды ең алғаш ана тілінежәне шетел тілінеүйретудеверботональды әдіс ең тиімді тәсілдердің бірі екендігн дәлелдеген француз академигі Петар Губерина жайлы сөз қозғалады. Сонымен қатар есту қабілеті нашар балалар бір уақытта сөйлеуді және қабылдауды үйренеді, яғни осы әдіс арқылы ауызша сөйлеу қабілеті қалыптасып дамиды. Сондай-ақ, П.Губерина жалпы лингвистикалық мәселелерді - тілдегі дыбыс пен қозғалысты, ырғақ пен ономатопеяны зерттегені туралыжәне есту және сөйлеу қабілеті бұзылған балаларды оңалтудың әдісін жасады.

Ағылшын тілін оқытуда сөйлеу әрекетінің - айтылым, оқылым, жазылым, тыңдалымжолдары тиімді қолданылса, және тапсырмаларәрбаланың ерекшеліктерінежәне тапсырма мазмұны тілдік дайындық деңгейіне сәйкес беріліп, оларға жекесараланған тапсырмалар мен нұсқаулықтарды нақты көрсету қажеттілігі, бөлінген уақыт қатаң дәлелді болуы. Осы шарттардың орындалуы сабақтың материалын түрлендіріп қана емес, сонымен бірге тақырыпты жақсы түсінуге ықпал ететіндігі мазмұндала келе естуінде ауытқуы бар оқушыларды қалыпты ортаға(социумға)бейімдеу болып табылады.

Түйінді сөздер: естуінде ауытқуы бар, верботональды әдіс, лингвистика, дыбыс пен қозғалыс, ырғақ пен ономатопея,сөйлеу әрекетінің түрлері, сараланған тапсырмалар, СУВАГ» орталығы, қалыпты ортаға(социумға)бейімдеу.

\author{
Autayeva Akbota ${ }^{1}$, Seitimbetova Saltanat ${ }^{2}$ \\ ${ }^{12}$ AbaiKazakh national pedagogical university, \\ Almaty, Kazakhstan
}

\section{BASICS OF USING THE VERBOTONAL METHOD IN TEACHING ENGLISH TO STUDENTS WITH HEARING DISABILITIES}

